Vol. 5, No. 2, 2019

Tetiana Rumilets

\title{
MEDIA LIBRARY AS A PROGRESSIVE MULTIFUNCTIONAL SPACE
}

\author{
Assistant Professor Urban Planning Department \\ Odessa State Academy of Civil Engineering and Architecture, Architectural and Art Institute; \\ e-mail: Tanya.rumilets@gmail.com
}

Received: 05.06.2019 / Revised: 27.07.2019 / Accepted: 05.08.2019

(C) Rumilets T., 2019

\begin{abstract}
The article considers the evolution of the public library, the modern functional zones of the library and their importance in the life of society. The international experience of developing public libraries was analyzed. It reveals that the library had turned into a multimedia library under the influence of technology, and later, under the influence of society, turned into a multimedia library center. A fourspace model for the functional purpose of the space of the modern library is considered. The model is used to build new libraries, modify existing libraries, and design the interiors of individual library spaces. Studies have found that the model embodies four common goals for the public library: Experience, Empowerment, Engagement and Innovation. A term for defining a "multimedia library center» was proposed.
\end{abstract}

Key words: Public library, media center, multimedia library, multifunctional space, media technologies, "4 spaces".

\section{Formulation of the problem}

Today the problem of introduction media technologies in the public libraries of Ukraine within the information multifunctional space is poorly studied. There are only publications of world experience and articles translated into Ukrainian by foreign colleagues. Weakly studied is the impact of information technology and social inquiry on the architectural and planning system of the modern libraries, as well as an emergence of a new typology of such buildings. In this regard, it is necessary to study the world experience and the IFLA model of "4 spaces" for its deep knowledge of construction and operation.

\section{Analysis of the research and publications}

The question of the study of the architecture and construction of libraries is relevant throughout the world. This is evidenced by the large number of scientific publications. There are the works of L. I. Alyoshin, A. B. Ander, A. R. Anisimova, S. Artamonova, O. Bashun, A. Valchak, V.M. Vinogradova, D. Gavretsky, L. S. Golovina, O. A. Dubinina, E. D. Zhabko, V. V. Zarudka, B. Zeltsle, K. B. Lavrova, I. Lelyuk, A. McDonald, V. Nefedova, Yu. P. Obrosov, V. V. Kutsevich, AP Patseli, L. O. Stepanova, K. E. Trubetskaya, G. M. Chernenko, I. S. Voronkova etc among them.

Significant theoretical and practical contribution to the development of problems of design and construction of library buildings was made by F. M. Paschenko. Mishkovsky covered the main issues of library 
design in his scientific work. He considered the principles of locating a library building in the city. In the late 80 's of the twentieth century the scientific works of A. R. Zimonenko and O. V. Anisimov were relevant for library design buildings. A. Zimonenko proposed the concept of mass media optimization libraries by diversifying the visitor's conditions. Instead of this O. Anisimov identified the basic requirements for a spatial organization libraries of higher educational establishments which consisted of communication and information kernel, in the application of multilevel volume, in using free planning and functional zoning.

It is important to note that there are no clear design guidelines for construction and renovation of different kinds of libraries in Ukrainian state building codes according to the 2019. There are no new standardized requirements for the structure and form of library buildings, their design, construction, technical and technological support. Nowadays the architects use regulatory requirements that were designed in the Soviet ages.

Analysis of the scientific literature showed that the questions of renovation, modernization, improving and developing the architectural environment of the libraries of higher education institutions in Ukraine are poorly understood. Scientific papers are mostly fragmentary. They devoid of full-scale examinations, critical analysis the current state of library facilities.

\section{The purpose of the article}

As a result of new functions and and their dependencies on information technologies and social request in the media centers, currently libraries need new models of activities, which takes into account the problems that society faces and at the same time shows the potential of the library of the future. The "Four spaces" model is a transforming a public library from a passive collection based space to a more active space for experience and inspiration and a local meeting point. This model needs learning and adaptation to Ukrainian realities.

\section{The Presentation material}

The development of the information society requires revision of the position and value of the institutions, which work with information, knowledge and culture. By the way, the impulse for reconsideration and development of libraries in the European community was a resolution, issued in October 1998 by the European Parliament, "The role of libraries in modern societies" (Ryynänen, The role of libraries in modern society, 1999). It was the first document on EU library policy. It identifies the needs for the most important panEuropean action in the libraries.

According to the document, libraries have been identified as one of the key elements of open access to information, which is crucial for the development of a democratic information society. The following paragraphs of this resolution testify to the first stages of rethinking the role of libraries in contemporary society and adapting it to the needs of the local community.

"Given that the best of public libraries also serve as a central social forum for the local community, where a lot of activities of the local community can be brought together and contribute to community development" (Ryynänen, 1988).

"The traditional image of the library is that it is a place where books are kept, but in modern-day society this is no longer accurate. Libraries may - and should - contain all media suitable for use at them. The most important access criterion at libraries is the quality of the material. Thus libraries primarily provide content rather than packaging according to particular models. The experience of libraries has been that new media do not supersede old. On the contrary, the various media support one another in the library context” (Ryynänen, 1988).

Currently, partly due of the publication of the document mentioned earlier, libraries have changed their appearance and added new functional areas. 

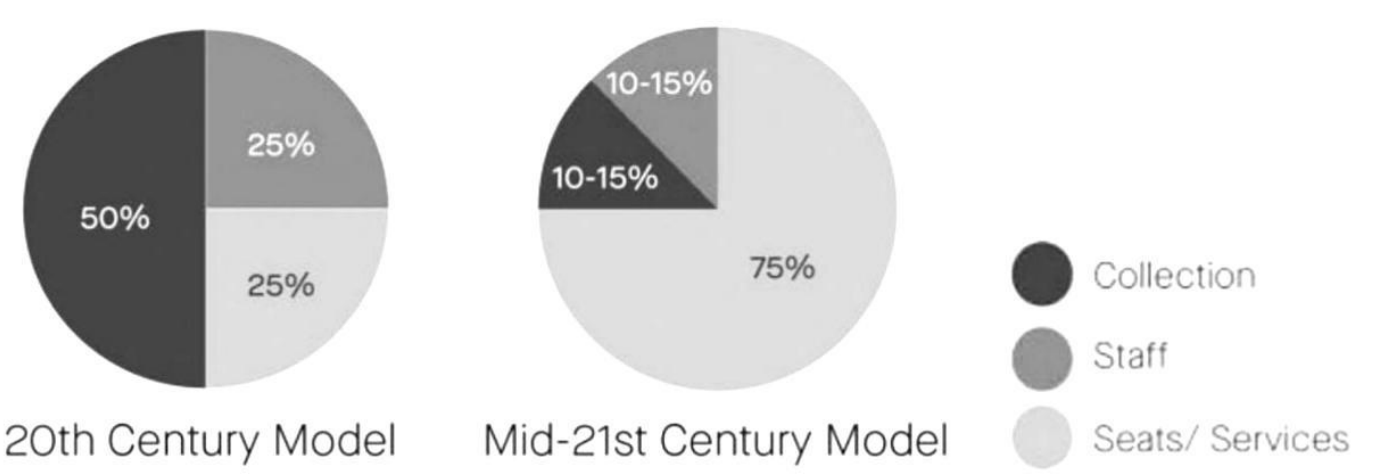

Fig. 1. The evolution of libraries. Zone ratios chart. Twenty-first century library space allocation (graphic by Shepley Bulfinch) (3)

The space in the library is divided into 3 main groups: funds, administration and the public part. The proportional ratio of the areas of these spaces has changed significantly compared to last century.

According to the schedule presented in Fig. 1, the area that used to hold funds in a typical library of the 20th century has nowadays decreased from the half of the total area of the library to $15 \%$, and so has the area reserved for administration decreased from $25 \%$ to $15 \%$, which has allowed the public space to increase to $75 \%$. (Koen, D., Lesneski, T. E., 2018)

In addition to traditional library functions and modern information technologies, a social and public functions are also required for the effective functioning of the library. Recently, it has become necessary to form a new paradigm of the information society, in which the role of the library has changed, and directly the reader-library interrelation is transformed into a simplified "user-library". It should also be noted that the word "reader" has disappeared from official documents, it is recommended to use "consumer", "user". In the new model: "in the work of libraries the transition marks from the paradigm of influence to the paradigm of interaction with readers, users and visitors". Also, the basic notion is the desire not to rebrand the existing standard library (change of visual design, name), but to create a new model of the library (Gushul, Y. V., Kozhenkin I. A., Lavrova K. B. 2013).

The Media Library is a multifunctional community complex that combines information and technology functions of a media object, educational and cultural and educative functions of a public library and social functions related to the local community, communicative and recreational space. The Media Library solves the problem of optimal interaction of information technologies and human, adaptation of the human being in the information environment and development of the cultural-genetic code of man and society (Fig. 2).

\section{Research results}

A comparative analysis of the education systems of the Scandinavian countries has led to the conclusion that the reform of the education system has touched all levels, based on common educational standards, universality and the widespread introduction of modern e-learning technologies in which libraries are not the last. The models of education systems in Finland, Sweden and Denmark are effective in the market for educational services, use advanced innovative experience, and acquire key competences related to lifelong learning (Tropnikova 2017).

Based on the analysis of world experience, we can conclude that the architectural and spatial solutions of libraries are significantly different from each other. They vary in a scale and number of their large and small functional spaces. However, most libraries, regardless of size and layout, have the same functional areas. The main functional areas of the modern library include the following preserved 
traditional, but transformed according to the requirements of the present: entrance group, administration, funds, children's area; and contemporary areas: a common public area, a researching space, a study space, a workshop space.

One of the most important tasks of a library designer is to ensure effective interaction between these different zones. Most often, functional areas are interconnected due to public space. (Fig. 3).

The four-factor model for space functional purpose is used to build new libraries, modify existing libraries, and design the interiors of individual library spaces. Ever since the model was launched, it has played a special role in embodying the concept of a space for creation - which describes the library as a space for creativity, innovation. The four-dimensional model is used not only in Denmark but also influences international library design trends. As is evident, the model embodies four common goals for the public library: Experience, Empowerment, Involvement and Innovation. Two of these goals - experience and empowerment clearly refer to classical library values such as education, cultural educative and social mobility. Other goals, that is, involvement and innovation, are more focused on new values related to concepts such as social capital, community cohesion, and empowering users to cope with today's ever-changing world (Jochumsen 2016).

Below are four different model spaces (Fig. 4). The four spaces beneath should be seen as intentions according to certain rooms in the library. One physical room can have more than one spatial intention. At most libraries, four spatial intentions coexist - outworked and mixed in different ways: learning, experiencing, meeting and creating.

Learning space is the space were children, youngsters and adults can discover and explore the world and thereby increase their competences and possibilities through free and unrestricted access to information and knowledge. The library is a space for non-formal learning, as well as a space that facilitates formal schooling. In recent years, the emphasis on the library as a learning space has increased. This is due to the development of digital technologies and increased global competition, which underscores the importance of lifelong learning.

"The learning space" is based on discovering and learning something new. It offers, for example, informal learning courses, e-learning facilities, talks, access to knowledge resources and question \& answer services. This creates special requirements for "learning space". The strength of the library as a learning space is that learning becomes a dialogue-driven process, based on personal experience of users and learning needs in the informal space. It is an activity that typically requires retention of attention to a shared task. It also poses demands on equipment, PCs and work tables. It can therefore be an obvious choice to allocate such activities to secluded, semi-closed spatialities. In addition to providing access to analogue and digital information and knowledge, it is important for the library to facilitate learning by having well-equipped study spaces and group work spaces, while providing space for homework and open courses at the same time.

In addition, libraries should be clearly aware of young people's need for experiential learning through interactive social learning models. The library also needs to live up to an intention of providing a learning space for children, and in this case, it may not be a learning space in the style of an office environment that is needed, but a learning space that can support a more activity-based, playful approach to learning.

"The inspiration space" is based on experience. It will typically offer access to materials including literature, art, films, music, entertainment and games as well as events with artists and similar. At a time where ever more titles become accessible on different virtual platforms, the library's role is to a lesser degree to ensure that visitors find what they need, and to a higher degree that they also find what they did not know they needed. In this connection, it is a great challenge for libraries to guide the many different users efficiently and unobtrusively to experiences and activities that match their needs. 


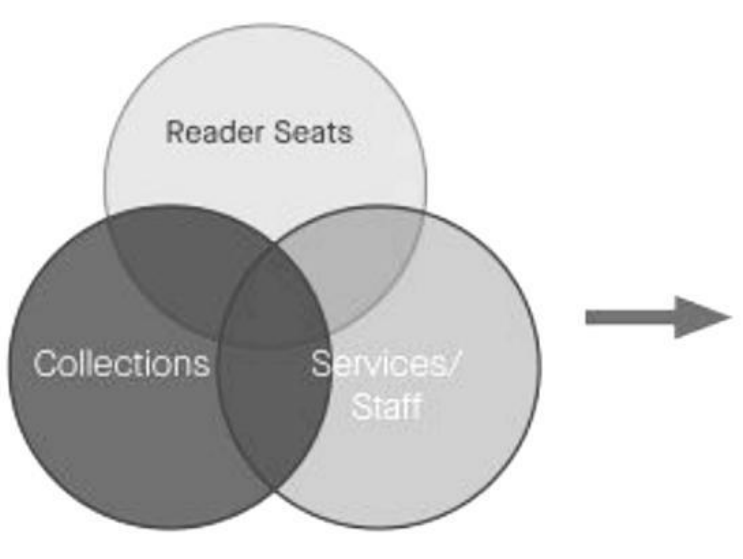

20th Century Model

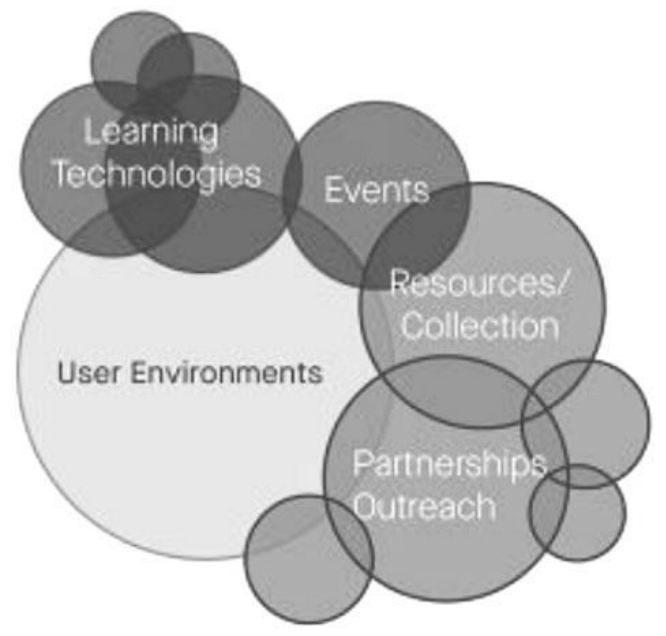

21st Century Model

Fig. 2. The evolution of libraries. $50 \%$ of availabe space is allocated to patrons (graphic by Shepley Bulfinch) (3)

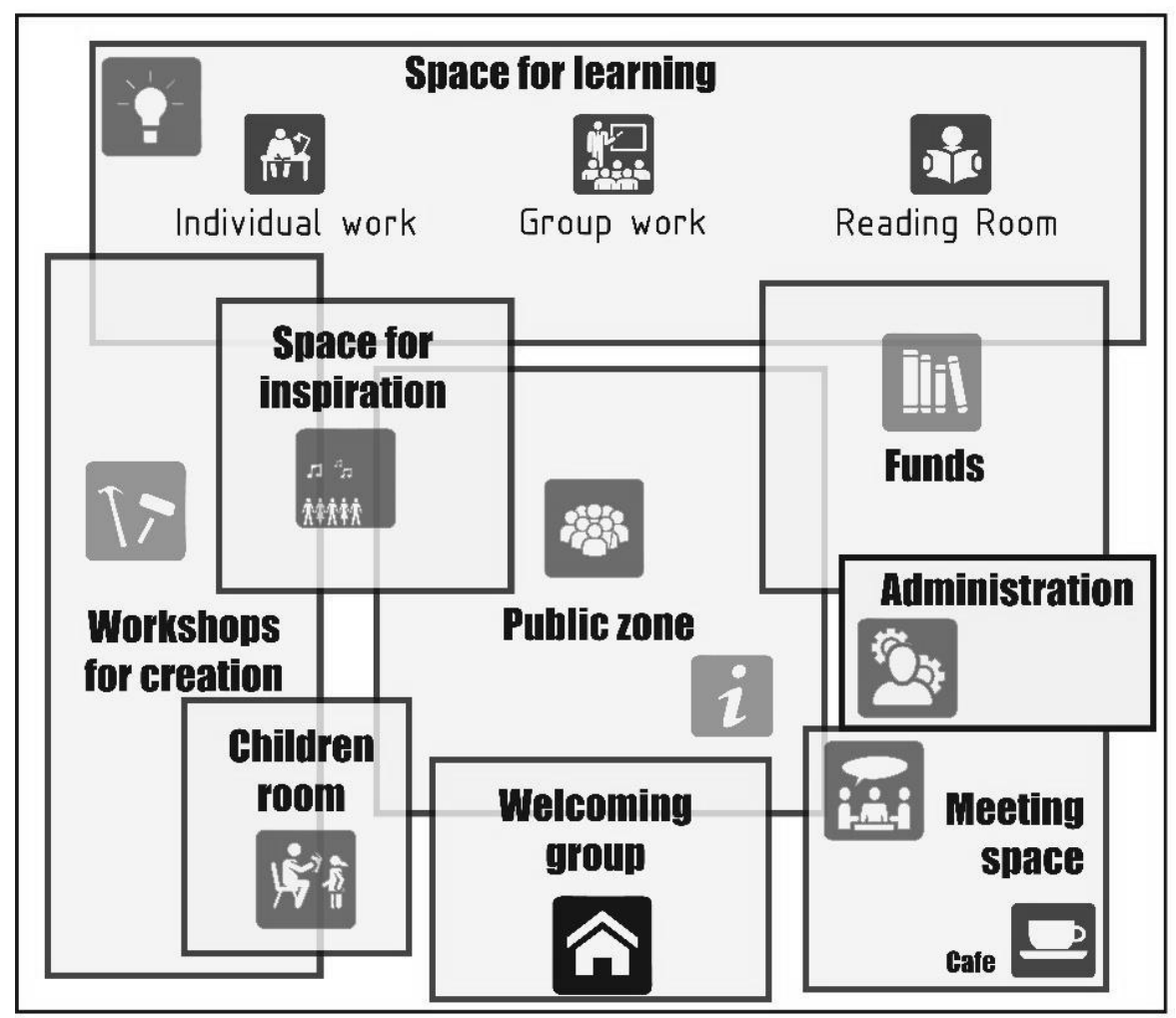

Fig. 3. Interaction of functional zones

Meeting Space is participation-based. It ranges from participating in local political issues, from reading and study circles to local community meetings. Meeting Space creates a space for the development of a passive community, such as library users reading in cafés. Special meetings are held for regular, scheduled events for external users, such as the local youth council. A growing number of libraries have their own café and cultivate architect Jan Gayle's view of engaging "passive communities" - where users prefer to be close to the street and activeness. However, numerous libraries have also decided to move their work or study space to the peripheral areas of the library. 


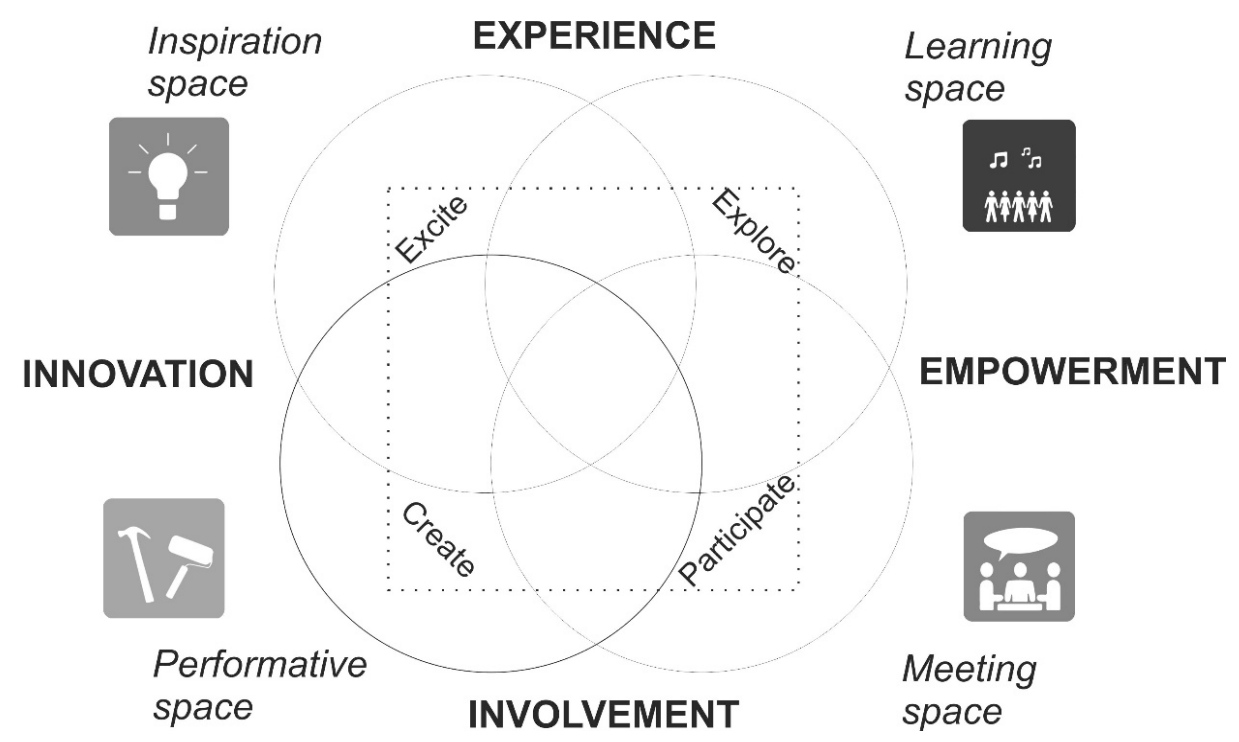

Fig. 4. The four spaces (graphic by Dorte Skot-Hansen, Henrik Jochumsen and Casper Hvenegaard Hansen) (10)

The library as a meeting room is an open, public space where you can meet like-minded people, but more importantly those who have different opinions and views, and discover a different position. The library has always been a meeting place for people, but our multicultural society draws attention to spaces where people's meetings can generate shared understanding and social cohesion. The concept of a "third space», that is, a place that is neither home nor work, often arises when considering the library as a meeting room. Another concept is a "low-intensity meeting place", which means that it gives us the opportunity to meet people who are different from us, unlike those in our usual fields of activity. The library can maximize its potential for meeting space by focusing on open spaces that facilitate interpersonal interaction - both casual and organized, such as meetings designed to discuss topics and issues. This requires the provision of spaces for casual meetings in small halls, lounge areas with newspapers and cafés, as well as spaces for larger, more organized meetings for public coverage and discussion of news or topics.

"Space to create" is based on creatively innovative user-driven activity. It aims at active creation, but this space can also be a creative and aesthetic learning space. It facilitates various seminars: writers' seminars, events with people of the arts, seminars on innovation. Specially equipped workspaces must be provided with space for listening and recording music, compact production laboratories and technologically equipped spaces that facilitate the study and implementation of innovations, and the space should provide safe storage for participants' work. Generally, Creation Space can be used by any visitor to the library. These can be hobbyists looking for equipment, space and new inspiration. Young people are connected to the creative field by looking for places where they can make and present their own creative endeavors, or creative entrepreneurs who need work space and meeting places. What is common about these different types of spaces for creation is that they involve a high degree of user involvement in interior design, workspace equipment and training.

Just as libraries have undergone a process of development "from collection to connection", we also refer to the "from collection to creation" transition. The library as a space for creation reflects this transition. Users can use the space to create with other users to get inspired and be able to create their own creative expressions or innovative solutions. In the creative space, users can also access tools and materials that support their creative work, and, where possible, they can get support from professional artists, designers, publishers and the distribution of users' work, as well as various events. In fact, the library as a space for creation is not something new, since libraries have previously served as a venue for various seminars. But the new so-called "digital generation" helps ensure that user engagement, userdriven innovation, and the overall transition from passive user to active co-founder are prominent libraries. In particular, the library as a space for creation can be maintained and developed, creating space for various informal seminars or in the form of direct workshops in the library (The Agency for Culture and Palaces n.d.). 


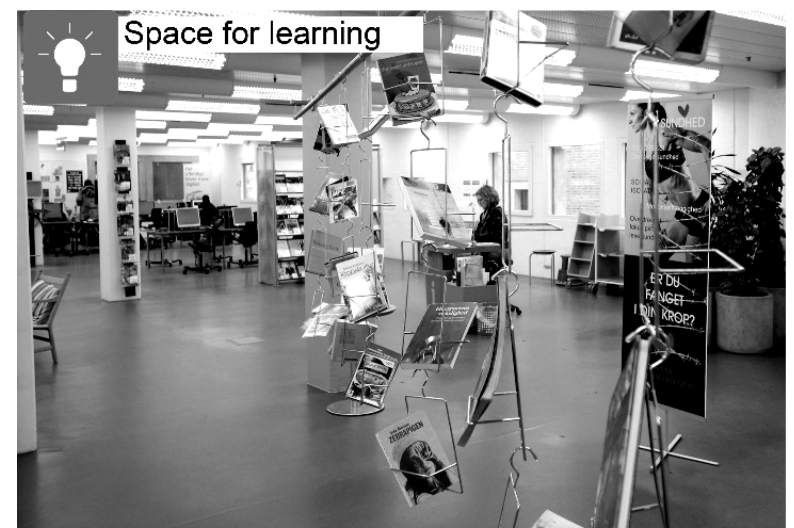

Central Library of Gentoft, Denmark.

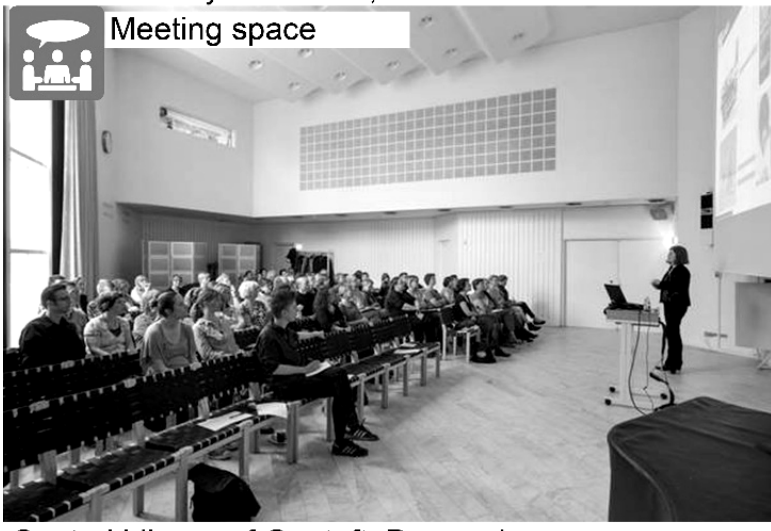

Central Library of Gentoft, Denmark.

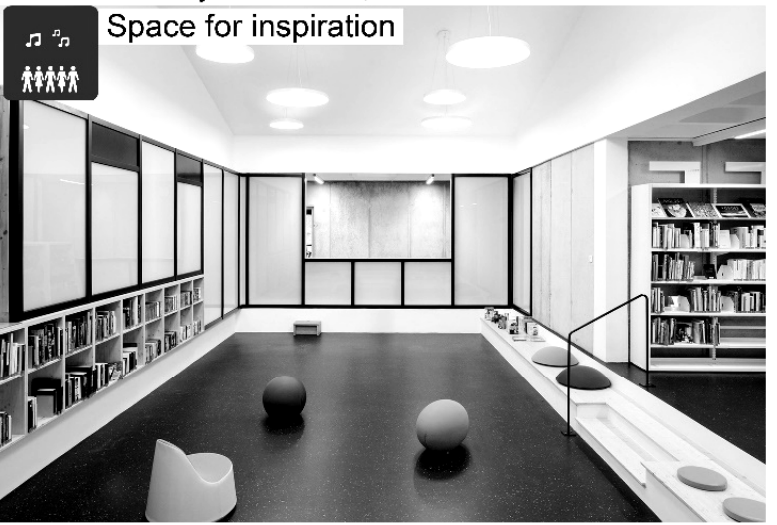

Lax Media Library, France.

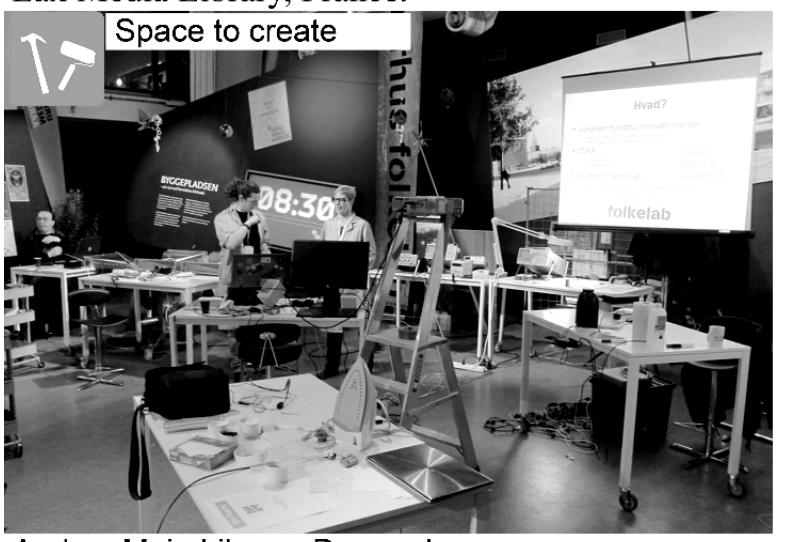

Aarhus Main Library, Denmark.

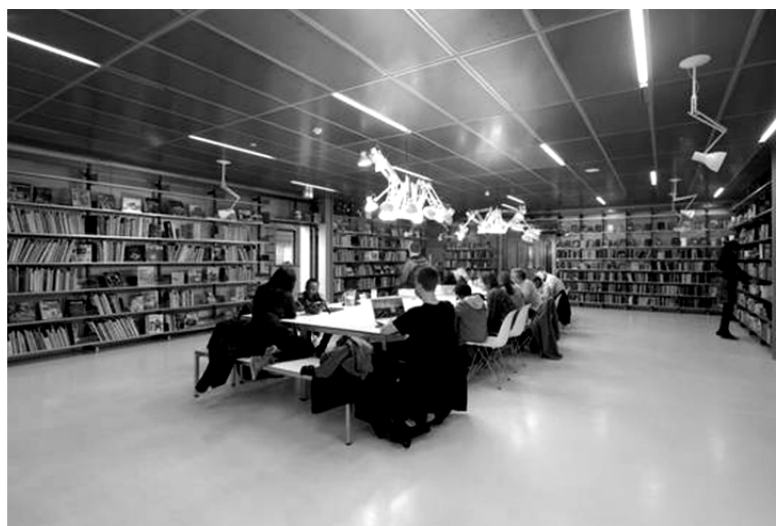

Copenhagen Public Library in Denmark.

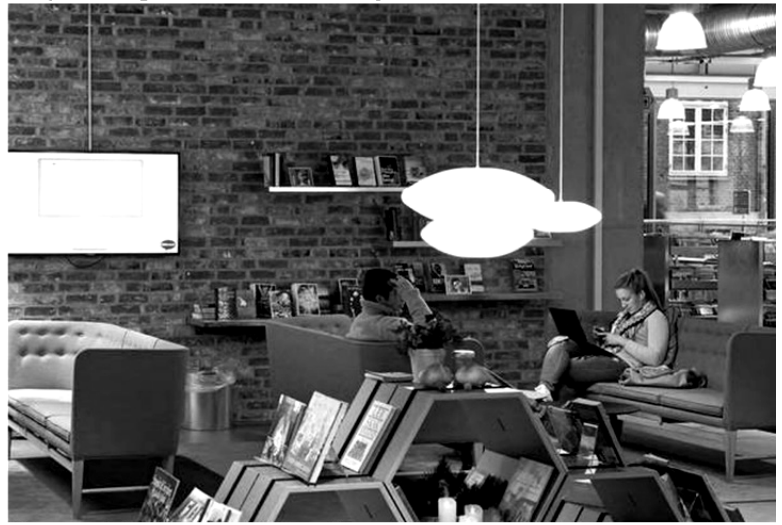

Central Library of Herning, Denmark.

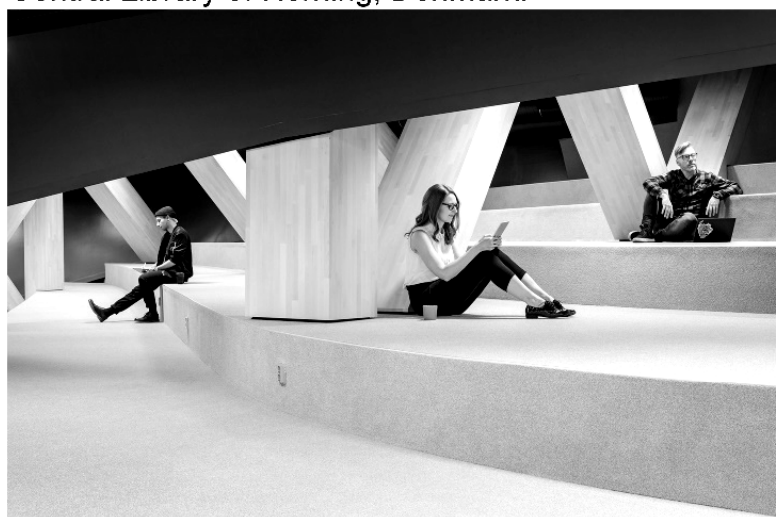

OODI Helsinki Central Library.

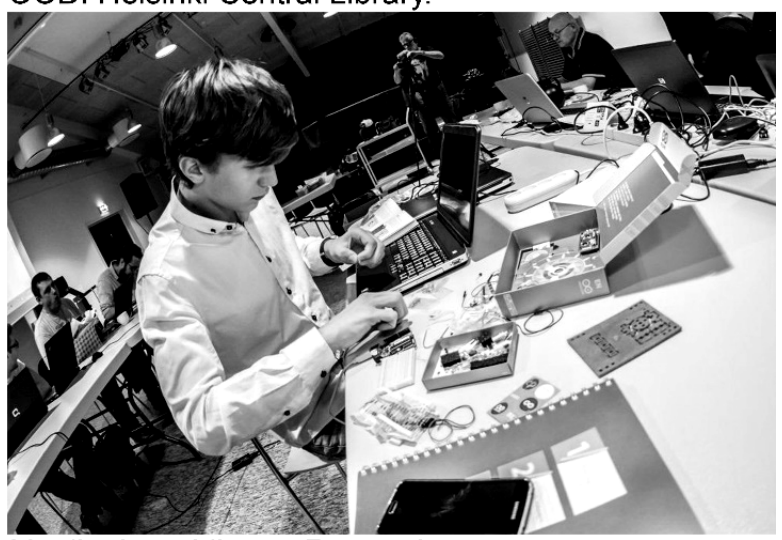

Vordingborg Library, Denmark.

Fig. 4. Examples of organizing the four functional zones 
The general public area, regardless of the size and plan of the solution, in almost all libraries will be a central area for people to stay and a meeting place. This "common square" often has a physical connection between the library's thematic material collections and the specialized premises. The common area is often one of the places in the library that should be able to support the largest number of different activities. It can be a setting for events, theater, reading or music. It may serve as a backdrop for submitting material collections or may include a seating area. It can also be a shared room used by many library users, who are not so much searching for collections as they are collecting or using as a study site.

The most widespread in the common area are the elements such as the stage, showcases and cafés.

A stage is another object in public space that needs to be a permanent fixture or can also be easily organized with a quick space adaptation.

Showcases. The second component in the common area may be showcases or digital installations that can support changing exhibitions where the library uses text, images and sound to focus on the author, art form, or time.

Café on the common area. Effective functioning of the café in the common area of the library can contribute to the continued stay of visitors. Especially during large-scale cultural events when the total area was transformed into a stage with seating.

Café may in the first place enhance the function of the library as a meeting room, but it can also cause people to stay a little longer, encourage spontaneous visits, and ideally it can be an open invitation to use other functions of the library. It should accommodate groups of people who talk, rest or work together, as well as individual users.

In this way, the café can help support the library's function as an open space for public meetings where citizens can meet other people in a random context within the library. It is especially important that the café interacts effectively with library stock such as periodicals (The Agency for Culture and Palaces, Model programme for public libraries n.d.).

\section{Conclusion}

The modern library has turned from a storage place for books to a multifunctional public space. The study of new features revealed four main functional areas, namely: study space, space for inspiration, space for meeting, space for creation. The overall purpose of these four spaces is to support the following four goals for the public library in the future: experience, participation, empowerment, innovation. It is an inspiration for the use of media, exhibitions, meetings, events, finding information, support for empowerment and education in daily life, personal advisory services. It is a learning space that supports media literacy and general education. It provides a space for user-centric activity and engages users through interactive activities that encourage social interaction and daily living. The Four Spaces model can be used by libraries in many ways. It can be used as a tool for rebuilding an existing library or as a tool for creating new libraries, such as libraries in newly created united territorial communities.

Public libraries promote community development, shape social capital and quality of life in different ways for different groups of people. Public libraries can have a positive impact on the quality of life in the following areas: the state and fundamental human rights, education, leisure and social interaction; not forgetting the role they play in three other areas (economic and physical security, productivity and core activity, health). The development of libraries and library services in accordance with the model of the world space (experience, participation, empowerment and innovation) will help them to create communities that contribute to improving the quality of life of people in their local communities.

The term "Media Library" was proposed and defined. It should be noted that media libraries are beginning to become navigators in an endless array of information, and this sets them apart from other communicative public structures. The basic information function of the public library today is connected not only with providing access to information resources of the society, but also acquiring a resource-evaluation and resource-orientation character. Not only do media centers actively promote the transition of society to the 
information age, but also strengthen its democratic and humanistic foundations, and become an important factor in ensuring its sustainable development.

\section{References}

[1] Gushul, Y. V., Kozhenkin I. A., Lavrova K. B. "Modern Library as a Designed Sociocultural Space.» Bulletin of the Chelyabinsk State Academy of Culture and Arts, 2013: 79-85.

[2] Jochumsen, H. The four-space model. Copenhagen, 2016.

[3] Koen, D., Lesneski, T. E. Library Design for the 21st Century: Collaborative Strategies to Ensure success . IFLA, 2018.

[4] Ryynänen, Mirja. Resolution on the role of libraries in modern societies. The European Parliament, 1988.

[5] "The role of libraries in modern society.» 7th Catalan Congress. 1999. 20.

[6] The Agency for Culture and Palaces. Model programme for public libraries . без дати. https://modelprogrammer. slks.dk/en/.

[7] The Library as a Performative Space. без дати. https://modelprogrammer.slks.dk/en/challenges/zones-and-spaces/thelibrary-as-a-performative-spacาe/.

[8] Tropnikova, V.V. "International experience of reforming higher education systems on the example of the Scandinavian countries.»Scientific and Methodical Electronic Magazine “Concept”, No. 12 (2017): 246-257.

\section{Тетяна Румілеиь}

\section{МЕДІАТЕКА ЯК ПРОГРЕСИВНИЙ БАГАТОФУНКЦІОНАЛЬНИЙ ПРОСТІР}

Анотація. У статті розглянуто еволюиію публічної бібліотеки, сучасні функиіональні зони бібліотеки та їх 3 значимість у житті суспільства. Було проаналізовано закордонний досвід розвитку публічних бібліотек. Виявлено, щцо бібліотека перетворилася на медіатеку під впливом технологій, а згодом, під впливом соиіуму, перетворилась на медіа бібліотечний центр. Цифрова ревоволючія привнесла нові методи використання інформаціі, культурні навички, шляхи комунікації та роботи та нові економічні та законодавчі умови (авторське право). Прорив інтернету 20 років тому змінив основи бібліотеки та парадигма “забезпечувати доступ до інформачії” потроху втрачає значення. Зараз існує попит на гнучкість, та здатність бути інноваційним. У публічних бібліотек та медіатек набагато різноманітнішою стала група користувачів та ширші цілі. Головні тренди у нових послугах - ие більш активне навчання та соціальна діяльність, заходи з медіа та громадської грамотності, семінари, місие зустрічей, щоденна інформація про життя. IFLA пропонуе чотири сценарії бібліотека традиційна, бібліотека “електронна”, “Бібліотека як місце подій”, “Вітальня громади”. Розглянуто модель чотирьох чинників для функиіонального призначення простору сучасної бібліотеки. Модель використовується для побудови нових бібліотек, модифікаиії існуючих бібліотек та дизайну інтер'єрів окремих бібліотечних просторів. Дослідження виявили, щэо модель втілює чотири загальні иілі для публічної бібліотеки: Досвід, Розширення можливостей, Залучення та Інновації. Запропоновано термін для визначення “медіабібліотечного иентру”.

Ключові слова: публічна бібліотека, медіа-центр, медіа-бібліотечний центр, багатофункціональний простір, медіа-технології, модель чотири простори. 